\title{
水素酸素分圧比センサによる水素燃料再使用ロケットにおける漏洩検知の試み
}

\section{Leakage Detection by Hydrogen/Oxygen Concentration Ratio Sensor in Hydrogen-fueled Reusable Rocket}

○正 丸 祐介*1, 鈴木 健吾*2, 宮崎 洋*2, 杜 泰成 ${ }^{* 2}$, 八木下 剛" ${ }^{* 1}$, 入門 朋子*1

Yusuke MARU*1, Kengo SUZUKI*2, Hiroshi MIYAZAKI*2, Yasunari YUZURIHA ${ }^{* 2}$, Tsuyoshi YAGISHITA*1 ${ }^{* 1}$ and Tomoko IRIKADO*1

*1 宇宙航空研究開発機構 Japan Aerospace Exploration Agency

*2 新コスモス電機株式会社 New Cosmos Electric Co., Ltd.

Key Words : Leakage detection, Hydrogen/oxygen concentration ratio sensor, Reusable rocket experiment

宇宙ロケットでは，上昇するにしたがって大気が薄くなり，必然的に酸素がない環境となる．また，現在の口 ケットの打上げにおいては，打上げ前の地上静止状態で，防爆および湿気対策のために，ロケット筐体内を窒素 ガスで充満させる運用が行われている。この場合，ロケット筐体内は，圧力は大気圧であるが，酸素量は大気よ りも極端に少ない環境となっている。このように，ロケットが経験する環境全域にわたって，ロケット笚体内で の燃料漏洩を検知するためには，動作に酸素を必要としないセンサが必要になる.

著者らは, 動作に酸素を必要としない水素センサの開発を行っている. このセンサは, 水素と酸素の濃度比 (分 圧比）に応じた信号を出力することが特徵である(1).このセンサを, 水素燃料再使用ロケットの実験機(2)に搭載し, 燃料漏洩検知を行うことを検討している，本講演では，本センサをロケットの地上燃焼実験に適用し，実験運用 した結果を報告する.

\section{○再使用ロケット実験機 RV-X と本水素センサの搭載}

再使用ロケット実験機 RV-X は，液体水素と液体酸素を推進剤とするロケットエンジン 1 基を搭載した，垂直 離着陸型の飛行実験機である．実験機の実運用による要素技術のシステムレベルでの実証が目的である．燃料漏 洩検知機能は, 再使用ロケットに必要な要素技術として, また, 実験の安全な実施のための保安機器として必要 となる，その手段として，RV-Xには，著者らの動作に酸素を必要としない水素センサが 2 台搭載されている.

\section{○本水素センサの事前機械環境試験}

ロケットの環境は，自動車など地上の輸送システムと比べて苛烈になる．ロケットに搭載する機器の検証試験 の一環として，本センサも機械環境試験に供された．本講演では，機械環境試験の様子についても紹介寸る.

\section{実験機搭載状態での標準ガスを用いた機能確認}

RV-X 機体に 2 台の水素センサを搭載した状態で，5\%水素-窒素バランスの標準ガスをロケット筐体内に微量 放出し, そのときのセンサ出力挙動を確認し, センサの機能確認を行った.

\section{○地上燃焼実験における本センサの出力挙動}

ロケットエンジンの地上燃焼実験では, タンクへの推進剤の注液を行い, その後, ターボポンプや配管の予泠 を行った上で，エンジン運転が行われる．その一連の手順の最中，2台のセンサの出力履歴を取得した．吸引式 の接触燃焼式センサでは反応しない状況でも, 本センサの出力挙動が確認された. 本センサは非常に微量の水素 ガスにも反応することが確認された.

\section{文献}

(1) Suzuki, K., Miyazaki, H., Yuzuriha, Y., Maru, Y., and Izu, N., "Characterization of a Novel Gas Sensor using Sintered Ceria Nanoparticles for Hydrogen Detection in Vacuum Conditions”, Sens. Actuators, B: Chemical, Vol. 250 (2017), pp. 617-622.

(2) Nonaka, S., T. Nakamura, and T. Ito., "Study on Flight Demonstration for Reusable Vehicle Experiment RV-X", ISTS-2019-g01, Fukui, Japan (2019). 